\title{
PENGARUH PEMBERIAN TERAPI KELOMPOK TERAPEUTIK ANAK USIA TODDLER TERHADAP PERKEMBANGAN PSIKOSOSIAL ANAK USIA TOLLER
}

\author{
Livana PH*, Yulia Susanti \\ Program Studi Ilmu Keperawatan dan Ners, Sekolah Tinggi Ilmu Kesehatan Kendal \\ *livana.ph@gmail.com
}

\begin{abstract}
ABSTRAK
Karakteristik anak usia toddler di kota Kendal bervariasi: ada yang sangat ceria saat bermain dengan anak yang lain, ada yang tampak mudah kesal, ada yang menangis ketika melihat orang baru, dan ada anak yang cenderung memilih bermain sendiri. Perkembangan kepribadian saling berkaitan dengan hubungan sosial. Kombinasi perkembangan kepribadaian dan hubungan sosial disebut perkembangan psikososial. Perkembangan psikososial pada anak usia toddler dapat dicapai secara optimal melalui peran serta orangtua. Upaya yang dapat dilakukan perawat dalam mencegah keterlambatan perkembangan psikososial anak usia toddler yaitu dengan menstimulasinya melalui terapi kelompok terapeutik (TKT) untuk meningkatkan respons motorik, kognitif, emosional dan psikososialnya. Penelitian bertujuan untuk menganalisis pengaruh terapi kelompok terapeutik terhadap perkembangan psikososial anak usia toddler. Penelitian dilakukan di Bandengan, Kota Kendal. Desain penelitian quasi experiment dengan rancangan penelitian pre and post test without control group dengan menggunakan Purposive sampling berjumlah 42 anak. Hasil penelitian dianalisis menggunakan paired $t$ test. Hasil penelitian menunjukkan ada pengaruh pemberian terapi kelompok terapeutik anak usia toddler terhadap perkembangan psikososial anak usia toller denga nilai $\mathrm{p}=0,000$.
\end{abstract}

Kata kunci: terapi kelompok terapeutik anak usia toddler, perkembangan psikososial anak usia toddler

\section{THE EFFECT OF PROVIDING THERAPEUTIC THERAPY FOR TODDLER-AGE CHILDREN ON THE PSYCHOSOCIAL DEVELOPMENT OF TOLL-AGE CHILDREN}

\begin{abstract}
The characteristics of toddler-age children in Kendal city vary: some are very cheerful when playing with other children, some look irritable, some cry when they see a new person, and there are children who tend to choose to play alone. Personality development is related to social relations. The combination of personality development and social relations is called psychosocial development. Psychosocial development in toddler age can be achieved optimally through parental participation. Efforts that nurses can take to prevent delays in toddler psychosocial development are to stimulate them through therapeutic group therapy (TKT) to improve their motor, cognitive, emotional and psychosocial responses. The research aims to analyze the effect of therapeutic group therapy on the psychosocial development of toddler age children. The study was conducted in Bandengan, Kendal City. Quasi experiment research design with pre and post test without control group research design using purposive sampling totaling 42 children. The results of the study were analyzed using the paired $t$ test. The results showed that there was an effect of therapeutic therapy for toddler age children on the psychosocial development of toll-age children with $p=0,000$.
\end{abstract}

Keywords: therapeutic group therapy for toddler, psychosocial development of toddler

\section{PENDAHULUAN}

Masa toddler merupakan pertumbuhan dan perkembangan anak usia $>18$ bulan hingga 3 tahun yang mengalami peningkatan yang sangat pesat. Anak sangat peka terhadap lingkungan, dan menggunakan kemampuan motorik yang telah dimilikinya untuk mengeksplorasikan lingkungan (Ardita, 2012). Anak toddler telah melewati terbentuknya rasa percaya berhubungan dengan orang lain yang didapatnya ketika usia infant. Kegagalan pada tahap infant 
dalam mengasuh/ merawat, maka akan tumbuh rasa tidak percaya pada tahap selanjutnya (Wulandari, 2016).

Studi Unisef (2013) di University of Rochester School of Medicine and Dentistry, menunjukkan anak yang tinggal bersama kerabat menggalami resiko gangguan kesehatan mental, sosial dan fisik dibandingkan dengan anak yang dirawat orang tua kandung (Unisef, 2015). Hal tersebut memperlihatkan bahwa anak yang tinggal bersama dengan kerabat, memiliki kesehatan mental, sosial dan fisik secara keseluruhan buruk dibandingkan dengan anak yang diasuh orang tua kandung (Meita,2012; Dewi, 2011; Heriweni, 2014). Masalah tersebut dapat dicegah, jika pengasuh atau orangtua paham akan perkembangan psikososial yang normal dan menyimpang yang terjadi pada anak khususnya anak usia toddler.

Hasil studi pendahuluan yang peneliti lakukan pada 3-5 September 2018 di kelurahan kelurahan Bandengan, Kota Kendal didapatkan data 12 anak usia toddler mempunyai kepribadian yang berbeda. Perbedaan kepribadian merupakan perpaduan antara emosi, tempramen, pikiran, dan prilaku yang membuat individu menjadi unik. Data didapatkan 5 dari 12 anak sangat ceria saat bermain dengan anak yang lain, 3 anak tampak mudah kesal ketika bermain dengan teman seusianya, 2 anak menangis ketika melihat orang baru, dan ada 2 anak cenderung memilih bermain sendiri. Perkembangan kepribadian saling berkaitan dengan hubungan sosial. Kombinasi perkembangan kepribadaian dan hubungan sosial disebut perkembangan psikososial. Perkembangan psikososial pada anak usia toddler dapat dicapai secara optimal melalui peran serta orangtua (Whalter, Keliat, B.A, Hastono 2010). Upaya yang dapat dilakukan perawat dalam mencegah keterlambatan perkembangan psikososial anak usia toddler yaitu dengan menstimulasinya melalui terapi kelompok terapeutik untuk meningkatkan respons motorik, kognitif, emosional dan psikososialnya. Berdasarkan studi pendahuluan tersebut, maka perlu dilakukan penelitian tentang implementasi keperawatan jiwa pada anak usia toddler di kota Kendal dalam upaya pencegahan keterlambatan perkembangan psikososial melalui terapi kelompok terapeutik. Tujuan penelitian ini untuk untuk menganalisis pengaruh terapi kelompok terapeutik terhadap perkembangan psikososial anak usia toddler melalui penelitian kuantitatif.

\section{METODE}

Penelitian ini menggunakan desain quasi experiment dengan rancangan penelitian pre and post test without control group dengan menggunakan Purposive sampling berjumlah 42 anak beserta pengasuhnya (orangtua anak usia toddler) yang terbagi dalam 5 kelompok kecil. Penelitian ini dilaksanakan di Bandengan kota Kendal pada bulan April hingga Juli 2019. Pengumpulan data menggunakan kuesioner tentang perkembangan psikososial anak usia toddler yang sebelumnya telah dilakukan uji validitas dan reliabilitas sehingga layak digunakan sebagai alat pengumpul data. Intervensi keperawatan spesialis keperawatan jiwa diberikan pada responden setelah responden dilakukan pengukuran awal terkait perkembangan psikososial anak usia toddler (pre test). Selanjutnya responden diberikan intervensi berupa terapi kelompok terapeutik selama 6 sesi yang terbagi dalam 3 pertemuan. Pada pertemuan terakhir responden dilakukan pengukuran kembali terkait perkembangan psikososial anak usia toddler (post test). Hasil penelitian dianalisis menggunakan paired $t$ test.

\section{HASIL}

Tabel 1 menunjukkan bahwa hasil analisis rata-rata umur responden 30 bulan dengan standar deviasi 0,578. Usia responden yang tertua yaitu 36 bulan dan usia termuda yaitu 22 bulan.

Tabel 1.

Usia Responden $(n=42)$

\begin{tabular}{ccccc}
\hline Variabel & Mean & Median & SD & Min-Max \\
\hline Usia & 29,89 & 30 & 0,578 & $22-36$ \\
\hline
\end{tabular}


Jurnal Keperawatan Jiwa Volume 7 No 2 Hal 227 - 230, Agustus 2019

FIKKes Universitas Muhammadiyah Semarang bekerjasama dengan PPNI Jawa Tengah

Tabel 2.

Karakteristik responden $(n=42)$

\begin{tabular}{lcc}
\hline \multicolumn{1}{c}{ Variabel } & f & $\%$ \\
\hline Jenis Kelamin & & \\
Laki-Laki & 28 & 67 \\
Perempuan & 14 & 33 \\
\hline
\end{tabular}

Tabel 3.

Perubahan perkembangan psikososial sebelum dan sesudah pemberian terapi kelompok terapeutik usia toddler $(n=42)$

\begin{tabular}{lccccc}
\hline \multicolumn{1}{c}{ Pengukuran } & Min & Max & Mean & SD & P value \\
\hline Pre-test & 8 & 22 & 14,5 & 3,842 & \multirow{2}{*}{0,000} \\
\hline Post-test & 18 & 25 & 22,5 & 5,024 & \\
\hline PEMBAHASAN & & & &
\end{tabular}

PEMBAHASAN

Hasil penelitian menunjukkan bahwa rata-rata responden berusia 30 bulan. Usia 30 bulan rentang usia toddler yang mempunyai kemampuan melepas pakaiannya seperti: baju, rok, atau celananya, berjalan naek tangga sendiri, mampu menunjuk anggota badan tanpa bantuan, mampu makan nasi tanpa banyak tumpah, mampu memungut mainannya sendiri, dan mampu menendang bola tanpa berpegangan. Hasil penelitian ini sejalan dengan pendapat Nasutin (2006) bahwa apabila pertumbuhan dan perkembangan anak pada aspek fisik, psikis dan intelegensia terpenuhi secara optimal, maka pada saat usia antara 1-3 tahun, ia akan menunjukkan perkembangan yang sangat menakjubkan. Hasil penelitian ini senada dengan pendapat Hartanto, Selina, Zuhriah, dan Fitra (2016) bahwa perkembangan psikososial memiliki pengaruh terhadap perkembangan kognitif anak usia 1-3 tahun. Hasil penelitian ini bertentangan dengan penelitian yang pernah dilakukan Latifah, Hastuti, dan Latifah (2010) bahwa stimulasi perkembangan psikososial paling baik terjadi pada anak yang berusia lebih dari 4,5 tahun.

Responden dalam penelitian ini seluruhnya mempunyai perkembangan psikososial dalam kategori normal dan mayoritas responden berjenis kelamin laki-laki. Hasil penelitian ini berbeda dengan penelitian Hartanto, Selina, Zuhriah, dan Fitra (2016) bahwa anak dengan jenis kelamin laki-laki lebih banyak mengalami keterlambatan bahasa. Hal ini mendukung pernyataan Sidiarto (2002) bahwa rasio laki-laki dibandingkan perempuan mencapai 8:1. Meskipun demikian jenis kelamin perempuan ternyata mampu menerima stimulasi psikososial lebih baik dibandingkan anak dengan jenis kelamin laki-laki (Latifah, Hastuti, \& Latifah, 2010). Temuan ini dimungkinkan bahwa jenis kelamin perempuan memiliki respon lebih positif terhadap stimulasi yang diberikan. Adanya respon positif tersebut, menyebabkan orangtua akan memberikan stimulasi yang semakin positif pula. Hal ini sejalan dengan teori operantconditioning yang dipopulerkan oleh Skinner bahwa adanya respon atau jawaban, maka akan menimbulkan penguatan atau rangsangan (Gunarsa 2003).

Penelitian ini dilaksanakan dengan membagi responden menjadi 5 kelompok kecil, dimana masing-masing kelompok terdiri dari 8-9 anak usia toddler beserta pengasuhnya yaitu orangtua toddler. Pemberian terapi kelompok terapeutik terlaksana dengan baik dan sesuai dengan konsep teori Townsend (2005) bahwa terapi kelompok terapeutik memberikan kesempatan kepada anggotanya untuk saling berbagi pengalaman, saling membantu satu dengan lainnya, untuk menemukan cara menyelesaikan masalah dan mengantisipasi masalah yang akan dihadapi.

Hasil penelitian terkait pengaruh perkembangan psikososial sebelum dan sesudah pemberian terapi kelompok terapeutik usia toddler menunjukkan bahwa ada pengaruh pemberian terapi kelompok terapeutik terhadap perkembangan psikososial anak usia toddler dengan nilai $p=0,000$ ( $p$ value $<0,05$ ). Hasil penelitian ini mendukung penelitian Hati dan Lestari (2016) bahwa ada pengaruh pemberian stimulasi pada anak usia 12-36 tahun. Hasil penelitian ini juga senada dengan penelitian Hartanto, Selina, dan Fitra (2016) bahwa ada pengaruh perkembangan bahasa terhadap perkembangan kognitif pada anak usia 1-3 
tahun. Hasil penelitian ini sesuai pendapat Diana (2010) bahwa perkembangan menimbulkan perubahan, menentukan perkembangan selanjutnya, mempunyai kecepatan yang berbeda-beda, berkorelasi dengan pertumbuhan, mempunyai pola yang tetap, dan mempunyai tahap yang berurutan.

\section{SIMPULAN}

Ada pengaruh pemberian terapi kelompok terapeutik todder dengan perkembangan psikososial anak usia todder.

\section{DAFTAR PUSTAKA}

Ardita V., Kadir A., \& Askar M. (2012). Deteksi Perkembangan Anak Berdasarkan DDST di RW I Kelurahan Luminda Kecamatan Wara Utara Kota Palopo. Volume 1 Nomor 2 Tahun 2012. ISSN : $2302-1721$

Dewi (2011). Faktor Dominan Karakteristik Ibu yang Berhubungan Dengan Pertumbuhan Dan Perkembangan Balita Usia 2-5 Tahun Diwilayah Kerja Puskesmas Nanggalo Kota Padang Tahun 2011. Skripsi. Universitas Andalas.

Diana, F. M. (2010). Pemantauan perkembangan anak balita. Jurnal Kesehatan Masyarakat Andalas, 4(2), 116-129.

Gunarsa SD. (2003). Dasar dan Teori Perkembangan Anak. Jakarta: BPK Gunung Mulia.

Hariweni, T. , Ali M, Sofyani S, Lubis IZ. (2004). Knowledge, Attitude, And Practice Of Underfive Children Stimulation Of Working And Nonworking Mothers. Paediatrica Indonesiana Volume 44, No.3-4, March-April 2004: 51-54

Hartanto, F., Selina, H., Zuhriah, H., \& Fitra, S. (2016). Pengaruh perkembangan bahasa terhadap perkembangan kognitif anak usia 1-3 tahun. Sari Pediatri, 12(6), 386-90.

Hati, F. S., \& Lestari, P. (2016). Pengaruh Pemberian Stimulasi pada Perkembangan Anak Usia 12-36 Bulan di Kecamatan Sedayu, Bantul. Jurnal Ners dan kebidanan indonesia,4(1), 44-48.

Latifah, E., Hastuti, D., \& Latifah, M. (2010). Pengaruh pemberian asi dan stimulasi psikososial terhadap perkembangan sosial-emosi anak balita pada keluarga ibu bekerja dan tidak bekerja. Jurnal Ilmu Keluarga \& Konsumen, 3(1), 3545 .

Meita.(2012). Anak Diasuh Orang Lain Berpotensi Gangguan Mental.From:http://meitadwi.blogspot.c om/2012/03.Diakses tanggal 25 September 2015

Nasution,Z. (2006). Asuhan keperawatan keluarga dengan anak balita an pra sekolah fakultas kedokteran program studi keperawatan. Medan: USU

Townsend, M. C, (2009), Psychiatric Mental Healt Nursing : Concepts of Care in Evidence-BasedPractice (6th ed.), Philadelphia : F.A. Davis

Sidiarto L. (2002). Gangguan perkembangan bahasa dan bicara pada keterlambatan bahasa. dalam simposium neuropediatri " child who does not speak ". Semarang : Badan Penerbit Universitas Diponegoro; h.7-13.

Unicef Indonesia. (2015). Laporan Tahunan Indonesia 2015. UNICEF (2015) baseline/endline survey results in Sikka, Klaten and Jayawijaya Districts.

UNICEF. (2013). Keadaan Anak di Dunia 2013, Rangkuman Eksekutif Anak Penyandang Disabilitas. Unicef: Unite for Children

Walter, Keliat., B.A, Hastono, S.P. (2010). Pengaruh Terapi Kelompok Terapeutik terhadap Perkembangan Industri Anak Usia Sekolah di Panti Sosial Asuhan Anak Kota Bandung. http://ejournal.stikesppni.ac.id/index.php/keperawatan-binasehat/article/view/334/334. 